\title{
KETAHANAN DUA PULUH SATU VARIETAS PADI TERHADAP PENYAKIT HAWAR DAUN BAKTERI
}

\author{
Heru Adi Djatmiko ${ }^{1}$ dan Fatichin ${ }^{1}$
}

\begin{abstract}
Resistance of twentyone rice varieties to Bacterial Leaf Blight. Bacterial leaf blight is one of the most important diseases of rice plants. Resistant Variety is one of safe, effective, and environment friendly alternative controls to suppress the bacterial leaf blight on rice. The objectives of this research were to find the most resistant varieties against bacterial leaf blight, and to study the yield of inoculated rice varieties. The research was carried out experimentally. This experiment was arranged in Randomized completely block design with 22 treatments and three replicates. Varieties of IR64 as control for susceptible varieties. Observed Variables were incubation period, disease intensity, seed weight per panicle, and seed weight per hills. The result of this research showed that variety IR 70 was the most resistant variety to bacterial leaf blight. Variety having highest yield was Rojolele with seed weight per hill was $31.17 \mathrm{~g}$.
\end{abstract}

Key words: Bacterial leaf blight, resistance, Xanthomonas oryzae pv. oryzae

\section{PENDAHULUAN}

Peningkatan produksi padi menemui banyak kendala di antaranya adanya penyakit hawar daun bakteri (Yashitola et al., 1997; Kadir, 1999; Tjubarjat et al., 1999; Suparyono et al., 2004). Salah satu penyakit penting padi sawah di Indonesia dan negara Asia adalah hawar daun bakteri yang disebabkan oleh Xanthomonas oryzae pv. oryzae (Kadir, 1999; IRRI, 2003). Di Indonesia, kehilangan hasil yang diakibatkan oleh penyakit tersebut dapat mencapai 70-80\% (Kadir, 1999), sedangkan di India mencapai 6\%-60\% dan Jepang mencapai 20\%-50\% (IRRI, 2003), sehingga mengakibatkan kerugian yang besar secara ekonomi (Yasin et al., 2005).

Berbagai upaya pengendalian penyakit hawar daun bakteri telah dilakukan di antaranya dengan antibiotik, oxytetracycline, streptomycin, dan chloramphenicol (Khan et al., 2005); peramalan (Liu et al., 2006); sanitasi (IRRI, 2003); dan kombinasi antagonis Pantoea agglomerans, Pseudomonas fluorescens, dan Bacillus subtilis AS (Babu \& Thind, 2005). Pengendalian tersebut belum memberikan hasil yang memuaskan karena $X$. oryzae mempunyai tingkat keragaman yang tinggi yang disebabkan oleh lingkungan, varietas yang digunakan, dan mengalami mutasi gen yang tinggi (Keller et al., 2000).
Penggunaan varietas tahan merupakan cara pengendalian yang paling efektif, murah, dan ramah lingkungan (Tjubarjat et al., 1999). Selain itu, penggunaan varietas tahan merupakan cara pengendalian yang paling umum dan mudah dilakukan oleh petani (IRRI, 2003). Berdasarkan pemikiran tersebut, maka diperlukan penelitian pengujian ketahanan varietas padi terhadap penyakit hawar daun bakteri untuk mendapatkan varietas padi yang paling tahan.

Tujuan penelitian ini adalah: (1) mendapatkan varietas padi yang paling tahan terhadap penyakit hawar daun bakteri, dan (2) mengkaji pengaruh penyakit hawar daun bakteri terhadap hasil dari masing-masing varietas padi yang diuji.

\section{METODE PENELITIAN}

Penelitian dilaksanakan pada bulan Maret sampai Juni 2007 di rumah kaca Fakultas Pertanian Unsoed. Rancangan yang digunakan adalah RAK (Rancangan Acak Kelompok) dengan 22 perlakuan dan 3 ulangan. Varietas IR 64 sebagai pembanding varietas yang rentan terhadap penyakit hawar daun bakteri. Tiap unit perlakuan terdiri atas 3 rumpun padi, sehingga total unit perlakuan ada 198 rumpun padi. Perlakuan tersebut meliputi:

${ }^{1}$ Jurusan Hama dan Penyakit Tumbuhan, Fakultas Pertanian, Universitas Jenderal Soedirman,

J1. Dr. Soeparno Karang Wangkal Purwokerto 53123 Purwokerto. Email : heru_adi@yahoo. com 
V1 : Varietas padi IR 64 (varietas pembanding yang rentan)

V2 : Varietas padi Code

V3 : Varietas padi Angke

V4 : Varietas padi IR 68

V5 : Varietas padi Sitantanur

V6 : Varietas padi Cimelati

V7 : Varietas padi Cirata

V8 : Varietas padi IR 70

V9 : Varietas padi Rokan

V10 : Varietas padi Bengawan Solo

V11 : Varietas padi Atomita

V12 : Varietas padi Cilosari

V13 : Varietas padi Mentikwangi

V14 : Varietas padi Poso

V15 : Varietas padi Punggur

V16 : Varietas padi Cisadane

V17 : Varietas padi Fatmawati

V18 : Varietas padi Gilirang

V19 : Varietas padi Rojolele

V20 : Varietas padi PB 5

V21 : Varietas IR72

V22 : Varietas Pepe

Pencarian inokulum. Pencarian inokulum dilakukan dengan cara : isolasi bakteri dari daun bergejala hawar daun bakteri dengan cara menumbuhkan pada medium SPA dengan komposisi sukrosa $20 \mathrm{~g}$, pepton $5 \mathrm{~g}$, $\mathrm{K}_{2} \mathrm{HPO}_{4} 0,5 \mathrm{~g}, \mathrm{MgSO}_{4} 7 \mathrm{H}_{2} \mathrm{O} 0,25 \mathrm{~g}$, agar $15 \mathrm{~g}$, air steril $1000 \mathrm{ml}$, dengan $\mathrm{pH} 7,2-7,4$ (Fahy \& Hayward, 1983). Daun bergejala tersebut dibersihkan dengan air steril, dipotong dengan ukuran $5 \mathrm{~mm}$ x $5 \mathrm{~mm}$, dan direndam dalam air steril selama 5 menit, selanjutnya suspensi bakteri dari hasil rendaman daun bergejala dan air steril digoreskan pada medium SPA, diinkubasi selama 48-72 jam, sampai diperoleh koloni tunggal berwarna kuning. Dua puluh dua varietas padi, tanah dan pupuk kandang disiapkan di dalam pot plastik berdiameter $30 \mathrm{~cm}$, serta persiapan alat-alat yang akan digunakan.

Pelaksanaan penelitian. Bibit padi berumur 29 hari setelah semai ditanam dalam pot yang berisi media tanam berupa tanah dan pupuk kandang dengan perbandingan 3:1. Setelah beradaptasi, 6 hari kemudian semua ujung daun diinokulasi $X$. oryzae pv. oryzae dengan metode pengguntingan (clip-method) ujung daun (Babu et al., 2003), yaitu dengan cara menggunakan gunting yang sudah dicelupkan dalam suspensi $X$. oryzae pv. oryzae kerapatan $1,95 \times 10^{9} \mathrm{cfu} / \mathrm{ml}$. Selama penelitian, pemeliharaan dilakukan dengan cara menggenangi air setinggi $2 \mathrm{~cm}$, sedangkan penyiangan dilakukan secara manual.

\section{Pengamatan}

Masa inkubasi. Masa inkubasi dihitung dari saat inokulasi sampai munculnya gejala dalam satuan hari.

Intensitas penyakit. intensitas penyakit diamati sampai 63 hari setelah semai. Intensitas penyakit dihitung dengan rumus (Suparyono et al., 2004) :

$$
I P=\frac{a}{b} \times 100 \%
$$

Keterangan:

IP = intensitas penyakit

$\mathrm{a}=$ panjang gejala hawar daun bakteri $(\mathrm{cm})$

$\mathrm{b}=$ panjang daun secara keseluruhan $(\mathrm{cm})$

Ketahanan tanaman padi terhadap penyakit hawar daun bakteri. Diukur menurut cara yang dikembangkan oleh Suparyono et al. (2004) dan Yashitola et al. (1997), yaitu:

\begin{tabular}{cc}
\hline Skala keparahan/intensitas penyakit & Reaksi tanaman \\
\hline$<10 \%$ & Tahan \\
$>10 \%$ & Rentan \\
\hline
\end{tabular}

Bobot gabah per malai dan bobot gabah per rumpun

Analisis Data. Data hasil pengamatan ketahanan (masa inkubasi dan intensitas penyakit) dianalisis secara deskriptif, sedangkan data hasil tanaman dianalisis dengan uji $\mathrm{F}$ dan bila berbeda nyata dilanjutkan dengan uji jarak berganda Duncan pada taraf 5\%.

\section{HASIL DAN PEMBAHASAN}

Respon 21 varietas padi terhadap penyakit hawar daun bakteri. Hasil pengamatan menunjukkan bahwa semua varietas yang diuji termasuk varietas pembanding yang rentan (IR 64) pada pengamatan 42 dan 49 hss dikategorikan tahan (Tabel 1). Varietas yang menunjukkan reaksi tahan pada pengamatan 56 hss yaitu Cimelati, IR 70, Rokan, Mentikwangi, Punggur, Cisadane, Fatmawati, Gilirang, Rojolele, PB 5, dan Pepe, sedangkan pada pengamatan 63 hss yang tahan hanya varietas IR 70 (Tabel 1). Waktu pengamatan dari 42 hss sampai 63 hss tersebut menunjukkan periode 
Tabel 1. Masa inkubasi dan intensitas penyakit hawar daun bakteri pada 21 varietas padi

\begin{tabular}{|c|c|c|c|c|c|c|c|c|c|}
\hline \multirow{2}{*}{ Perlakuan } & \multirow{2}{*}{$\begin{array}{c}\text { Masa } \\
\text { inkubasi } \\
\text { (hari) }\end{array}$} & \multicolumn{8}{|c|}{ Intensitas penyakit (\%) dan reaksi tanaman } \\
\hline & & $\begin{array}{l}42 \\
\text { hss }\end{array}$ & $\begin{array}{c}\text { Reaksi } \\
\text { tanaman }\end{array}$ & $\begin{array}{c}49 \\
\text { hss }\end{array}$ & $\begin{array}{c}\text { Reaksi } \\
\text { tanaman }\end{array}$ & $\begin{array}{l}56 \\
\text { hss }\end{array}$ & $\begin{array}{c}\text { Reaksi } \\
\text { tanaman }\end{array}$ & $\begin{array}{c}63 \\
\text { hss }\end{array}$ & $\begin{array}{c}\text { Reaksi } \\
\text { tanaman }\end{array}$ \\
\hline IR 64 (V1) & 3,00 & 2,64 & Tahan & 4,5 & Tahan & 16,20 & Rentan & 28,50 & $\overline{\text { Rentan }}$ \\
\hline Code (V2) & 4,00 & 1,18 & Tahan & 1,67 & Tahan & 10,12 & Rentan & 16,50 & Rentan \\
\hline Angke (V3) & 3,33 & 4,04 & Tahan & 5,06 & Tahan & 12,85 & Rentan & 22,80 & Rentan \\
\hline IR 68 (V4) & 3,33 & 1,35 & Tahan & 1,63 & Tahan & 11,34 & Rentan & 24,30 & Rentan \\
\hline Sintanur (V5) & 3,33 & 1,03 & Tahan & 2,87 & Tahan & 17,17 & Rentan & 25,80 & Rentan \\
\hline Cimelati (V6) & 4,00 & 1,14 & Tahan & 1,56 & Tahan & 3,65 & Tahan & 19,90 & Rentan \\
\hline Cirata (V7) & 3,00 & 1,38 & Tahan & 2,59 & Tahan & 11,74 & Rentan & 22,60 & Rentan \\
\hline IR 70 (V8) & 5,00 & 0,97 & Tahan & 1,59 & Tahan & 4,21 & Tahan & 9,69 & Tahan \\
\hline Rokan (V9) & 5,00 & 1,19 & Tahan & 1,78 & Tahan & 5,39 & Tahan & 10,30 & Rentan \\
\hline Bengawan Solo (V10) & 3,00 & 1,23 & Tahan & 4,34 & Tahan & 11,29 & Rentan & 33,80 & Rentan \\
\hline Atomita (V11) & 3,33 & 1,51 & Tahan & 2,96 & Tahan & 11,12 & Rentan & 25,60 & Rentan \\
\hline Cilosari (V12) & 3,00 & 1,53 & Tahan & 3,78 & Tahan & 18,45 & Rentan & 43,30 & Rentan \\
\hline Mentikwangi (V13) & 3,00 & 0,91 & Tahan & 3,06 & Tahan & 9,25 & Tahan & 40,00 & Rentan \\
\hline Poso (V14) & 3,33 & 1,74 & Tahan & 3,34 & Tahan & 14,47 & Rentan & 21,90 & Rentan \\
\hline Punggur (V15) & 4,00 & 1,57 & Tahan & 3,75 & Tahan & 6,39 & Tahan & 15,50 & Rentan \\
\hline Cisadane (V16) & 3,00 & 1,69 & Tahan & 4,47 & Tahan & 6,05 & Tahan & 29,70 & Rentan \\
\hline Fatmawati(V17) & 4,00 & 0,97 & Tahan & 1,89 & Tahan & 5,74 & Tahan & 14,60 & Rentan \\
\hline Gilirang (V18) & 3,33 & 1,37 & Tahan & 4,33 & Tahan & 8,98 & Tahan & 24,40 & Rentan \\
\hline Rojolele (V19) & 3,00 & 0,80 & Tahan & 2,49 & Tahan & 7,40 & Tahan & 25,50 & Rentan \\
\hline PB 5 (V20) & 4,00 & 0,81 & Tahan & 1,69 & Tahan & 3,85 & Tahan & 13,40 & Rentan \\
\hline IR 72 (V21) & 3,33 & 1,61 & Tahan & 4,59 & Tahan & 13,54 & Rentan & 21,00 & Rentan \\
\hline Pepe (V22) & 4,33 & 1,81 & Tahan & 2,31 & Tahan & 7,44 & Tahan & 11,60 & Rentan \\
\hline
\end{tabular}

Keterangan: hss $=$ hari setelah semai

infeksius dari $X$. oryzae pv. oryzae dan terjadi pada fase pertumbuhan vegetatif tanaman padi. Fase tersebut merupakan fase rentan terhadap penyakit hawar daun bakteri, sehingga periode pengamatan 42 hss sampai 63 hss adalah periode yang paling tepat untuk menentukan ketahanan tanaman padi. Hasil pengujian ketahanan tersebut menunjukkan bahwa varietas padi yang tadinya tahan menjadi rentan karena terjadinya patotipe $X$. oryzae pv. oryzae (Tjubarat et al., 1999). Saat ini di lapang, patotipe $X$. oryzae pv. oryzae di Indonesia yang mendominasi adalah patotipe IV, VIII, X, dan XII (Kadir, 1999) dan III, VII, dan VIII (Suparyono et al., 2004). Hal tersebut sesuai dengan pendapat Suparyono et al. (2004), bahwa patotipe yang mendominasi di daerah Jawa Tengah, Jawa Barat, dan Yogyakarta yaitu patotipe VIII (pada fase awal pertumbuhan) dan IV (pada fase pemasakan). Dominannya kedua patotipe tersebut menunjukkan pentingnya penyakit hawar daun bakteri di Indonesia.
Semua varietas yang diuji selain IR 70 bereaksi rentan sama dengan varietas pembandingnya yaitu IR 64 karena intensitas penyakitnya lebih dari $10 \%$ dan masa inkubasinya relatif cepat (3-4 hari setelah inokulasi). Menurut Suparyono et al., (2004), varietas IR 64 dan Cisadane bereaksi rentan terhadap X. oryzae pv. oryzae patotipe VIII, dan Mentikwangi terhadap $X$. oryzae pv. oryzae patotipe IV. Hal ini berkaitan dengan semakin meluasnya penanaman varietas IR 64 yang rentan terhadap penyakit hawar daun bakteri, sehingga timbul kelompok strain baru yang dominan di suatu wilayah (Kardin \& Hifni, 1993). Strain IR 64 mempunyai gen ketahanan $\mathrm{Xa}-\mathrm{-} 4$ yang sangat rentan terhadap isolat $X$. oryzae pv. oryzae asal Indonesia (Zhang \& Mew, 1989). Selain itu, kerentanan varietas padi terhadap $X$. oryzae pv. oryzae disebabkan oleh tingginya kandungan asam amino dan rendahnya kandungan polifenol (Fang et al., 1963 cit. Tjubarat et al., 1999). 
Ketahanan varietas IR 70 terhadap penyakit hawar daun bakteri pada 63 hss mempunyai respon positif karena intensitas penyakitnya kecil yaitu $9,69 \%$ atau kurang dari $10 \%$ dan masa inkubasinya 5 hari setelah inokulasi, sehingga menunjukkan varietas paling tahan dibandingkan dengan varietas lainnya. Hal ini sesuai dengan pendapat Nayak et al. (1986), bahwa pengaruh secara tidak langsung ketahanan tanaman padi terhadap penyakit hawar daun bakteri ditentukan oleh masa inkubasi dan area di bawah kurva perkembangan penyakit. Gen ketahanan terhadap ras X. oryzae pv. oryzae dikendalikan oleh gen R mayor (Liu et al., 2006). Selain itu, diduga bahwa suatu tanaman menjadi tahan karena tanaman tersebut menghasilkan fitoaleksin sebagai hasil interaksi inang-parasit yang fungsinya menghambat perkembangan bakteri. Menurut Babu et al. (2003), varietas padi yang tahan terhadap penyakit hawar daun bakteri menyebabkan meningkatnya kandungan fenol, terakumulasinya pathogenesisrelated $(P R)$ protein, dan thaumathin-like protein (TLP).
Pengaruh $X$. oryzae pv. oryzae terhadap komponen hasil. Nilai bobot gabah per malai yang ditunjukkan oleh setiap varietas beragam dari yang terkecil sampai terbesar. Bobot gabah per malai yang terbesar ditunjukkan oleh varietas Rojolele dan Mentikwangi yaitu 3,7 g, sedangkan bobot gabah per rumpun oleh varietas Rojolele yaitu $31,17 \mathrm{~g}$. Bobot gabah yang diperoleh sangat berkaitan dengan intensitas penyakit, intensitas penyakit rendah akan diikuti bobot gabah tinggi, tetapi dalam kenyataannya tidak selalu demikian. Hal ini diduga adanya kehampaan pada tanaman padi pada lingkungan tumbuh yang sempit. Menurut Soemartono et al. (1984), penyebab kehampaan yang berakibat menurunnya bobot gabah, yang paling umum dijumpai dalam budidaya adalah kerebahan dan inkompatibilitas. Selain itu, $X$. oryzae pv. oryzae patotipe VIII dan IV yang mendominasi di Indonesia, menunjukkan bahwa penyakit hawar daun masih menjadi ancaman terhadap produksi padi karena sebagian besar varietas yang ditanam rentan terhadap kedua patotipe tersebut (Suparyono et al., 2004).

Tabel 2. Bobot gabah per malai (g) dan bobot gabah per rumpun karena pengaruh X. oryzae pv. oryzae

\begin{tabular}{lcc}
\hline \multicolumn{1}{c}{ Perlakuan } & Bobot gabah per malai $(\mathrm{g})$ & Bobot gabah per rumpun $(\mathrm{g})$ \\
\hline IR 64 (V1) & $0,96 \mathrm{a}$ & $9,69 \mathrm{a}$ \\
Code (V2) & $1,11 \mathrm{a}$ & $11,89 \mathrm{abc}$ \\
Angke (V3) & $1,13 \mathrm{a}$ & $10,11 \mathrm{abcd}$ \\
IR 68 (V4) & $1,41 \mathrm{ab}$ & $9,89 \mathrm{a}$ \\
Sintanur (V5) & $3,00 \mathrm{bcd}$ & $21,83 \mathrm{cdefgh}$ \\
Cimelati (V6) & $2,01 \mathrm{abc}$ & $12,24 \mathrm{abc}$ \\
Cirata (V7) & $2,44 \mathrm{bcd}$ & $14,61 \mathrm{abcd}$ \\
IR 70 (V8) & $1,24 \mathrm{ab}$ & $9,66 \mathrm{ab}$ \\
Rokan (V9) & $1,39 \mathrm{ab}$ & $10,52 \mathrm{ab}$ \\
Bengawan Solo (V10) & $1,21 \mathrm{ab}$ & $16,46 \mathrm{abcdef}$ \\
Atomita (V11) & $1,51 \mathrm{ab}$ & $13,76 \mathrm{abcd}$ \\
Cilosari (V12) & $3,35 \mathrm{~cd}$ & $26,16 \mathrm{f}$ \\
Mentikwangi (V13) & $3,70 \mathrm{~d}$ & $24,00 \mathrm{efgh}$ \\
Poso (V14) & $1,90 \mathrm{ab}$ & $16,67 \mathrm{abcdef}$ \\
Punggur (V15) & $2,34 \mathrm{abcd}$ & $18,09 \mathrm{abcdef}$ \\
Cisadane (V16) & $1,52 \mathrm{ab}$ & $18,85 \mathrm{bcdef}$ \\
Fatmawati(V17) & $3,64 \mathrm{~d}$ & $21,95 \mathrm{cdef}$ \\
Gilirang (V18) & $2,47 \mathrm{bcd}$ & $22,91 \mathrm{def}$ \\
Rojolele (V19) & $3,7 \mathrm{~d}$ & $31,17 \mathrm{i}$ \\
PB 5 (V20) & $1,95 \mathrm{ab}$ & $15,43 \mathrm{abcd}$ \\
IR 72 (V21) & $2,14 \mathrm{abc}$ & 25,64 ef \\
Pepe (V22) & $1,13 \mathrm{ab}$ & $15,90 \mathrm{abcd}$ \\
\hline Keterangan: Angka yang diikuti oleh huruf yang sama pada kolom yang sama tidak berbeda nyata & \\
\multicolumn{1}{c}{ pada uji jarak berganda Duncan taraf 5\% } &
\end{tabular}


Menurut Tjubarat et al. (1999), bahwa varietas atau galur yang menunjukkan penampilan baik dan potensi hasilnya tinggi, walaupun intensitas penyakit tinggi dapat direkomendasikan untuk dilepas dengan harapan di lapang nanti termasuk yang toleran.

\section{SIMPULAN DAN SARAN}

\section{Simpulan}

1. Padi varietas IR 70 adalah varietas yang paling tahan terhadap penyakit hawar daun bakteri.

2.Varietas yang mempunyai hasil tertinggi adalah Rojolele dengan nilai bobot gabah per rumpun yaitu $31,17 \mathrm{~g}$.

\section{Saran}

1. Penelitian lanjutan perlu dilakukan terutama menentukan patotipe $X$. oryzae pv. oryzae.

2. Ketahanan 21 varietas padi terhadap penyakit hawar daun bakteri dan hasilnya perlu diteliti dalam skala lapang sehingga gambaran secara nyata tentang informasi varietas tersebut benar-benar dapat dipertanggungjawabkan terutama kepada petani.

\section{DAFTAR PUSTAKA}

Babu, A.G. \& B.S. Thind. 2005. Potential Use of Combinations of Pantoea agglomerans, Pseudomonas fluorescens, and Bacillus subtilis as Biocontrol Agents for the Control of Bacterial Blight of Rice. (On-line). http:// www.agridept.gov.lk/other_sub_pages.php?id=8. Diakses tanggal 5 Januari 2007.

Babu, R.M., A. Sajeena, A. V. Samundeeswari, A. Sreedhar, P. Vidhyasekeren, \& M.S. Reddy. 2003. Induction of bacterial blight (Xanthomonas oryzae pv. oryzae) resistance in rice by treatment with acibenzolar-S-methyl. (On-line). http://www3.interscience.wiley.com/ journal/ 118827857/abstract?CRETR Y=1 $\&$ SRETRY=0. Diakses tanggal 23 Oktober 2008.

Fahy, P.C. \& A.C. Hayward. 1983. Media and Methods for Isolation and Diagnostic Test. Pp. 337-378. In: P.C. Fahy \& G.J. Persley (Eds.), Plant Bacterial Disease. Academic Press, London.
IRRI. 2003. Bacterial Leaf Blight. (On-line). http:// www.knowledgebank.irri.org/ riceDoctor_MX/ $\mathrm{F}$ a c t $-\mathrm{Sh}$ e e t s/D i s e a s e s / Bacterial_Leaf_Blight.htm. Diakses tanggal 2 Januari 2007.

Kadir, T.S. 1999. Variasi Patogen Xanthomonas oryzae pv. oryzae. Prosiding Kongres Nasional XV dan Seminar Ilmiah PFI, Purwokerto, 16-18 September.

Kardin, M.K. \& H.R. Hifni. 1993. Penyakit Hawar Daun Bakteri Padi di Indonesia. Risalah Seminar Puslitbangtan, April 1992-Maret 1993.

Keller, B., C. Feuillet, \& M. Messmer. 2000. Basic Conceps and Application in Resistance Breeding. pp. 101-160. In: A.J. Slusarenko, R.S.S. Fraser, \& L.C. van Loon (eds.), Mechanisms of Resistance to Plant Diseases. Kluwer Academic Publisher. London.

Khan, T.U.Z., S.I. Yasin, M. Ayub, J.A. Shah, \& M. Ahmad. 2005. Effect of Different Chemicals and Antibiotics on Bacterial Leaf Blight (Xanthomonas oryzae pv. oryzae) of Rice. Mycopath 3: 57-59.

Liu, D.N., P.C. Ronald, \& A.J. Bogdanove. 2006. Xanthomonas oryzae Pathovars: Model Pathogens of A Model Crop. Molecular Plant Pathology 7: 303-324.

Nayak, P., A.V.S. Rao, \& N.K. Chakrabarti. 1986. Components of Resistance to Bacterial Blight Disease of Rice. (On-line). http://www3. interscience.wiley.com/journal/119481585/ abstract. Diakses tanggal 23 Oktober 2008.

Soemartono, B. Somat, \& Supihanto. 1984. Bercocok Tanam Padi. CV. Yasaguna, Jakarta.

Suparyono, Sudir, \& Suprihanto. 2004. Pathotype Profile of Xanthomonas oryzae pv. oryzae Isolates from the Rice Ecosystem in Java. Indonesian Journal of Agriculture Science 5: 63-69. 
Tjubarjat, T., T.S. Kadir, \& E. Sumadi. 1999. Skrining Varietas terhadap Hawar Daun Bakteri. Prosiding Kongres Nasional XV dan Seminar Ilmiah PFI, Purwokerto, 16-18 September.

Yashitola, J., D. Krishnaveni, A.P.K. Reddy, \& R.V. Sonti. 1997. Genetic Diversity Within the Population of Xanthomonas oryzae pv. oryzae in India. Phytopathology 87: 760-765.
Yasin, S.I., T.U.Z. Khan, M. Ayub, J.A. Shah, \& M. Anwar. 2005. Economic Evaluation of Bacterial Leaf Blight (Xanthomonas oryzae pv. oryzae) disease of rice. Mycopath. $3: 65-67$.

Zhang, Q. \& T.W. Mew. 1989. Types of Resitance in Rice to Bacterial Blight, Bacterial Blight Blight of Rice. Proceedings of The International Workshop on Bacterial Blight of Rice, 14-18 March 1998. Philippines. 